\title{
Late-gestation heat stress abatement on performance and behavior of Holstein dairy cows
}

\author{
M. T. Karimi, ${ }^{*}$ G. R. Ghorbani, ${ }^{*}$ S. Kargar, $†$ and J. K. Drackley $\ddagger^{1}$ \\ *Department of Animal Sciences, College of Agriculture, Isfahan University of Technology, Isfahan 84156-83111, Iran \\ †Department of Animal Sciences, College of Agriculture, Shiraz University, Shiraz 71441-65186, Iran \\ ‡Department of Animal Sciences, University of Illinois, Urbana 61801
}

\section{ABSTRACT}

The objective of this study was to evaluate cooling to lessen the effects of heat stress during the last 3 wk of gestation on performance and behavior of multiparous Holstein cows. Twenty nonlactating cows were randomly assigned to treatments approximately $21 \mathrm{~d}$ before their expected calving date based on mature equivalent milk production and parity. Treatments were only imposed during the last 3 wk of gestation and included heat stress $(\mathrm{HT} ; \mathrm{n}=10)$ and cooling $(\mathrm{CL} ; \mathrm{n}=$ 10), both under a similar photoperiod (14 h of light and $10 \mathrm{~h}$ of dark). Dry cows were housed in a sand-bedded stall with the stall areas for CL cows equipped with sprinklers and fans that were on from 0700 to $1900 \mathrm{~h}$, whereas those for the HT cows were not. After parturition, all cows were housed in a barn with cooling devices. Rectal temperatures were measured daily at 1400 $\mathrm{h}$ and respiration rates were recorded by counting the flank movements for $1 \mathrm{~min}$ at $1500 \mathrm{~h}$ on odd days over the last $3 \mathrm{wk}$ of gestation to calving. Daily dry matter intake was measured from $-21 \mathrm{~d}$ relative to expected calving to $21 \mathrm{~d}$ after calving and milk production was recorded daily up to $180 \mathrm{~d}$ in milk. Behavioral changes of dry cows were studied continuously for $24 \mathrm{~h}$ at -10 $\mathrm{d}$ relative to expected calving. The average temperature-humidity index during the last 3 wk of gestation was 69.7 and was not significantly different between treatments. Heat-stressed cows exhibited greater rectal temperatures ( 39.5 vs. $\left.39.2^{\circ} \mathrm{C}\right)$, greater respiration rates (70.4 vs. 63.3 breaths $/ \mathrm{min}$ ), and decreased dry matter intake (13.7 vs. $15.5 \mathrm{~kg} / \mathrm{d}$ ) compared with CL cows. Compared with HT cows, CL cows produced more milk during $180 \mathrm{~d}$ in milk (40.5 vs. $44.6 \mathrm{~kg} / \mathrm{d}$ ). Heat stress decreased ruminating (243.2 vs. $282.5 \mathrm{~min} / \mathrm{d})$ and chewing times (390.6 vs. $448.7 \mathrm{~min} / \mathrm{d}$ ) at $-10 \mathrm{~d}$ before

Received December 24, 2014.

Accepted May 29, 2015.

${ }^{1}$ Corresponding author: drackley@illinois.edu calving. The CL cows had shorter standing times than their HT counterparts (390.4 vs. $474.0 \mathrm{~min} / \mathrm{d}$ ). These results confirm that heat stress abatement in the late gestation period improves performance of dairy cows in subsequent lactation.

Key words: heat stress, temperature-humidity index, transition cow, cooling

\section{INTRODUCTION}

The close-up dry period is characterized by increasing immune dysfunction (Mallard et al., 1998) and declining energy balance (Drackley, 1999). During the dry period in dairy cows, mammary tissue undergoes extensive growth and cell turnover (do Amaral et al., 2011). The dry period is critical for maximal milk production in subsequent lactation, because in the absence of a dry period dairy cows produce significantly less milk in their next lactation (Grummer and Rastani, 2004). The transition period from the nonlactating to the lactating state imposes many stressors on dairy cows, which may impair DMI, milk production, and herd health. The success of the transition period (from the last 3 wk of gestation until the first 3 wk of lactation) effectively determines the profitability of the cows during lactation (Drackley, 1999). Nutritional, management, or environmental limitations during this period may impede the ability of cows to reach maximal milk production.

Effective environmental temperature is an environmental factor that affects welfare and performance of dairy cows (Kargar et al., 2015). Heat and humidity combine to decrease comfort of the environment for dairy cows. Heat stress negatively affects lactation and reproductive performance variables, especially DMI and milk production, and also increases disease incidence in lactating dairy cattle (Collier et al., 2006; Kargar et al., 2015). Heat stress in dry cows has resulted in decreased milk production in the subsequent lactation and compromised immune function in the transition period (do Amaral et al., 2010, 2011; Tao et al., 2011). During the transition period, dairy cows exhibit changes in their 
feeding, drinking, and standing behavior (Huzzey et al., 2005). In addition to negative effects on cows, heat stress during late gestation also is associated with lower birth weight of calves, which indicates compromised fetal growth (Collier et al., 1982b). The objectives of the present study were to evaluate the effect of heat stress abatement during the last 3 wk of gestation on production and reproductive performance and to assess the effects of heat stress on behavioral changes of late pregnant multiparous Holstein dairy cows.

\section{MATERIALS AND METHODS}

All procedures were conducted under protocols approved by the Isfahan University of Technology Laboratory Animal Care Advisory Committee. The experiment was conducted from June 20 to September 3, 2012, at the Farm Animal Research and Teaching Unit of Isfahan University of Technology in the region of Lavark near Najaf-Abad, Iran.

\section{Animals, Housing, and Experimental Design}

Twenty multiparous Holstein dry cows selected to be similar in parity and mature-equivalent (MEq) milk production of previous lactation were randomly assigned to treatments (10 cows per treatment) approximately $21 \mathrm{~d}$ before their expected calving date. Treatments were only imposed during the last $3 \mathrm{wk}$ of gestation and included either heat stress $(\mathbf{H T}$; BW $=714 \mathrm{~kg}$; BCS $=2.9$; parity $=3$; previous $\mathrm{MEq}$ milk yield $=11,380$ $\mathrm{kg}$ ) or cooling $(\mathbf{C L} ; \mathrm{BW}=727 \mathrm{~kg} ; \mathrm{BCS}=3.0$; parity $=3$; previous $\mathrm{MEq}$ milk yield $=11,750 \mathrm{~kg}$ ). Forty-eight calendar days elapsed between the first and last cow to give birth. Cows from both groups were subjected to a similar ambient photoperiod (approximately $14 \mathrm{~h}$ of light and $10 \mathrm{~h}$ of dark), with barn lighting installed over the stall areas being turned on and off manually at those intervals. The dry cows were housed in individual sand-bedded stalls $(4 \times 4 \mathrm{~m})$ in an open-sided barn, each equipped with a concrete feed bunk $(1 \times 0.5 \times$ $0.4 \mathrm{~m}$; length $\times$ width $\times$ height). Cows were allowed to exercise in an outdoor lot daily from 1600 to 1700 $\mathrm{h}$. The pen contained a corrugated sheet metal shade structure oriented north-south with an oscillating fan evaporative cooling system (model HU-110; IsfahanHavasaz Co., Isfahan, Iran) located at middle of each stall. The fans ( 1 per 2 cows) were $0.5 \mathrm{~m}$ in diameter with a 1.5-hp motor and delivered a maximum of 60 $\mathrm{L} / \mathrm{h}$ of water and moved air at $110 \mathrm{~m}^{3} / \mathrm{min}$. The air velocity was $11 \mathrm{~m} / \mathrm{s}$. The stall areas for the CL treatment were located $25 \mathrm{~m}$ from the HT treatment. Fans and sprinklers for CL cows were on from 0700 to 1900 $\mathrm{h}$, whereas those in the HT treatment were not. After parturition, HT cows were moved to individual stalls where the CL cows were located until $21 \mathrm{~d}$ postpartum, then all of them were introduced to the herd housed in a freestall system equipped with fans and sprinklers for cooling.

Air temperature and relative humidity of each pen were recorded every 15 min using a temperature and humidity data-logger (model ST-172; Fotronic Co., Melrose, MA). The temperature-humidity index (THI) was calculated based on the equation reported by Dikmen and Hansen (2009):

$$
\begin{aligned}
\mathrm{THI}=(1.8 \times & \mathrm{T}+32)-[(0.55-0.0055 \times \mathrm{RH}) \\
& \times(1.8 \times \mathrm{T}-26)],
\end{aligned}
$$

where $\mathrm{T}$ is air temperature $\left({ }^{\circ} \mathrm{C}\right)$ and $\mathrm{RH}$ is relative humidity (\%). In our study, THI categories developed for high-yielding lactating cows by Zimbelman et al. (2009) were used: thermal neutral $(<68)$, heat stress threshold (68 to 71 ), mild to moderate heat stress (72 to 79 ), moderate to severe heat stress ( 80 to 89 ), severe heat stress (90 to 98), and extremely severe heat stress $(>100)$. During the dry period, rectal temperature was measured daily at $1400 \mathrm{~h}$ using a rectal thermometer (Digital Thermometer MT101, Sejoy, Hangzhou, China) and respiration rate was measured by counting the flank movements for $1 \mathrm{~min}$ at $1500 \mathrm{~h}$ on odd days from the last 3 wk of gestation to calving. Both dry and lactating cows were fed TMR once daily at $0900 \mathrm{~h}$ to allow 5 to $10 \%$ refusals daily. Dietary ingredients were mixed for approximately $10 \mathrm{~min}$ in a TMR mixer wagon (Fan Avaran Keshavarzi Arya Co., Isfahan, Iran). After mixing, the ration was transferred to a feed cart (Iran Plast Co., Isfahan, Iran) from which cows were fed.

The same dietary composition was used for prepartum and postpartum diets in both treatments (Table 1). During the experiment, water was supplied to the cows for ad libitum consumption. The TMR amounts offered and refused were measured daily for each cow and DMI was determined daily for each cow from 21 $\mathrm{d}$ before expected calving to $21 \mathrm{~d}$ after calving. One sample of TMR and orts from each cow was collected on a weekly basis to calculate DM percentage. Cows were milked 3 times daily at 8-h intervals $(0200,1000$, and $1800 \mathrm{~h}$ ) in a milking parlor followed by $30 \mathrm{~min}$ of exercise after each milking. Milk production was recorded daily up to 180 DIM. Cows were weighed and body condition scored at $-21,-14,-7,0,7,14$, and 21 $\mathrm{d}$ relative to calving, before feeding when dry and after morning milking during lactation. Additionally, all calves $(\mathrm{n}=20 ; 10$ per treatment) were weighed when 
Table 1. Ingredients and chemical composition of TMR fed to Holstein cows during prepartum and postpartum periods

\begin{tabular}{|c|c|c|}
\hline \multirow[b]{2}{*}{ Item } & \multicolumn{2}{|c|}{ Diet } \\
\hline & Prepartum & Postpartum \\
\hline \multicolumn{3}{|c|}{ Ingredient composition, $\%$ of DM } \\
\hline Corn silage ${ }^{1}$ & 28.03 & 22.75 \\
\hline Alfalfa hay ${ }^{1}$ & 27.24 & 14.30 \\
\hline Beet pulp & - & 7.22 \\
\hline Barley grain, ground & 18.49 & 12.35 \\
\hline Corn grain, ground & - & 10.60 \\
\hline Wheat grain, ground & 6.17 & 9.34 \\
\hline Corn gluten meal & - & 1.80 \\
\hline Soybean meal & 4.34 & 9.74 \\
\hline Canola meal & 8.80 & - \\
\hline Cottonseed & - & 1.50 \\
\hline Soy-plus & - & 3.60 \\
\hline Rice bran & - & 2.98 \\
\hline Yellow grease $^{2}$ & - & 0.77 \\
\hline Sodium-bicarbonate & - & 0.99 \\
\hline Calcium carbonate & 0.81 & 0.62 \\
\hline Calcium phosphate (mono) & - & 0.15 \\
\hline Vitamin-mineral premix ${ }^{3}$ & 2.05 & 0.98 \\
\hline Anionic salt mixture $^{4}$ & 4.06 & - \\
\hline Salt & - & 0.31 \\
\hline \multicolumn{3}{|l|}{ Chemical composition } \\
\hline DM, \% & 59.9 & 51.6 \\
\hline $\mathrm{CP}, \%$ of $\mathrm{DM}$ & 14.7 & 16.2 \\
\hline NDF, $\%$ of DM & 37.0 & 32.2 \\
\hline $\mathrm{ADF}, \%$ of $\mathrm{DM}$ & 24.2 & 22.5 \\
\hline Ether extract, \% of DM & 2.2 & 3.7 \\
\hline $\mathrm{NE}_{\mathrm{L}},{ }^{5} \mathrm{Mcal} / \mathrm{kg}$ of DM & 1.53 & 1.59 \\
\hline
\end{tabular}

${ }^{1}$ Corn silage and alfalfa hay contained 10.2 and $14.7 \% \mathrm{CP}$ and 55.5 and $49.9 \%$ NDF, respectively.

${ }^{2}$ Composition (g/100 of total FA): C14:0 $=0.09 ;$ C16:0 $=11.85 ; \mathrm{C} 16: 1$ $=0.31 ; \mathrm{C} 18: 0=4.05 ; \mathrm{C} 18: 1=25.68 ; \mathrm{C} 18: 2=51.59 ; \mathrm{C} 18: 3=6.11$ and others $=0.32$.

${ }^{3}$ Supplied 800, 80, 100, 10, 18, 35.2, 0.12, 0.28, 0.17, and $12 \mathrm{mg} / \mathrm{kg}$ of diet DM of calcium, phosphorus, magnesium, copper, manganese, zinc, cobalt, iodine, selenium, and antioxidants, as well as vitamin A (3,000 $\mathrm{IU} / \mathrm{kg})$, vitamin D $(800 \mathrm{IU} / \mathrm{kg})$, and vitamin $\mathrm{E}(6 \mathrm{IU} / \mathrm{kg})$.

${ }^{4}$ Included calcium (22.5\%), magnesium (5.5\%), sulfur (5\%), and chlorine $(7.5 \%)$.

${ }^{5}$ Based on tabular values (Cornell Net Carbohydrate and Protein System; Fox et al., 2000)

born. Prepartum cumulative BW and BCS changes were calculated by subtracting values at -14 and -7 $\mathrm{d}$ relative to calving and at calving from those at -21 d. Postpartum cumulative BW and BCS changes were calculated by subtracting values at 7,14 , and $21 \mathrm{~d}$ relative to calving from those at calving.

\section{Sample Collection and Laboratory Analyses}

Milk samples were collected daily until $21 \mathrm{~d}$ postpartum and then monthly from 3 consecutive milkings with potassium dichromate used as the preservative. Milk samples were analyzed for fat, true protein, SNF, and SCC (MilkoScan 134 BN; Foss Electric, Hillerød, Denmark; AOAC International, 2002; method 972.16).
Somatic cell score was calculated according to the following equation: $\mathrm{SCS}=\left[\log _{10}(\mathrm{SCC} / 12.5)\right] / \log _{10}(2)$. Blood samples were collected $3 \mathrm{~h}$ after feeding on the day of calving and on d 45 postpartum from coccygeal vessels into sodium-heparinized Vacutainers (Becton Dickinson Co., Rutherford, NJ), which were immediately placed on ice and transported to the laboratory. Leucocyte abundance was assessed within $3 \mathrm{~h}$ of blood collection. Hematological analysis was performed on all blood samples using an Automated Sysmex hematology analyzer (model K-1000; Black Scientific Inc., Bellport, NY). The first milking after calving was considered colostrum, samples of which were collected and colostrum density was measured to determine its quality.

Samples of TMR, ingredients, and refusals (pooled by cow within prepartum and postpartum periods) were dried at $55^{\circ} \mathrm{C}$ in a forced-air oven for $48 \mathrm{~h}$ and ground to pass a 1-mm screen using a Wiley mill (Arthur H. Thomas Co., Philadelphia, PA). Chemical analyses were performed in duplicates (except for ether extract, which had 4 replications). Samples were analyzed for CP (AOAC International, 2002; method 955.04) and ether extract (AOAC International, 2002; method 920.39). Concentrations of NDF and ADF were sequentially analyzed (Van Soest et al., 1991) with heat-stable $\alpha$-amylase (Sigma A3306; Sigma-Aldrich, Steinheim, Germany) and sodium sulfite used in the NDF procedure.

\section{Behavioral Changes}

Behavioral changes in feeding, drinking, and standing were monitored visually by trained people for each cow over a 24 -h period at $-10 \mathrm{~d}$ relative to expected calving. A total of 6 individuals in 2-person teams rotated throughout the 24-h period; 2 individuals observed the cows simultaneously for $2 \mathrm{~h}$ with a 4 -h rest period before recording again. All activities including eating, ruminating, drinking, and standing were noted every 5 min, and each activity was assumed to persist for the entire 5-min interval between observations (Kargar et al., 2010, 2013, 2014). A period of rumination was defined as at least 5 min of rumination occurring after at least 5 min without rumination. A meal was defined as at least 1 observation of eating activity occurring after at least $26.4 \mathrm{~min}$ without eating activity. An instance of drinking was defined as at least 1 observation of drinking activity occurring after at least $5.3 \mathrm{~min}$ without drinking activity (Huzzey et al., 2005). The time spent eating, ruminating, and chewing (eating + ruminating) per kilogram of DMI and eating rate (total daily $\mathrm{DMI} /$ total eating time; $\mathrm{kg}$ of $\mathrm{DM} / \mathrm{min}$ ) were calculated (Kargar et al., 2010, 2014). Daily idle standing time 


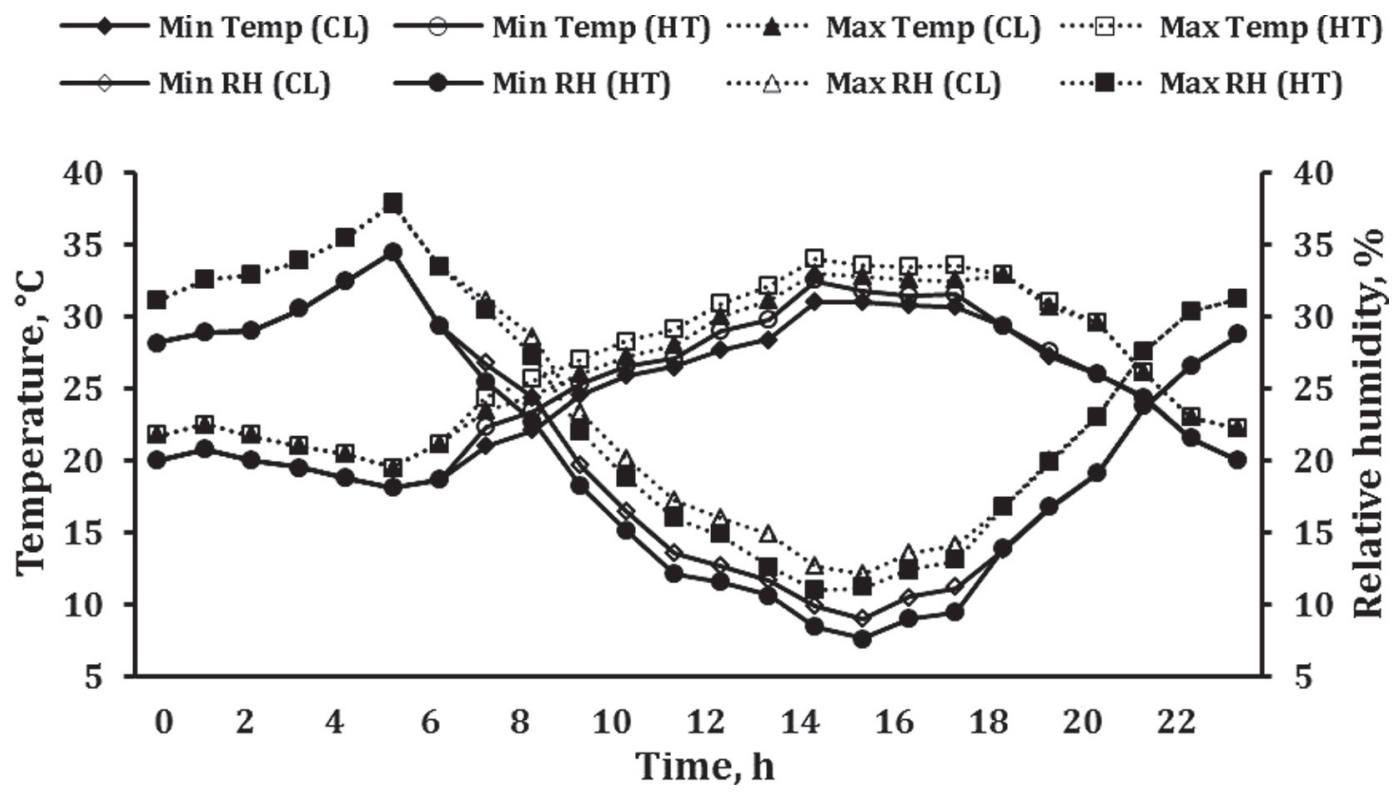

Figure 1. Average daily diurnal pattern of barn temperature (Temp) and relative humidity (RH) during the precalving period.

(i.e., the time cows spent standing without eating or drinking) was calculated as the difference between daily standing times.

\section{Statistical Analyses}

Data were evaluated for normality of residuals distribution before analysis (Proc Univariate; SAS Institute, 2002). Data were analyzed using the MIXED procedure of SAS (Proc Mixed; SAS Institute, 2002). The repeated measurements of milk production, milk composition, rectal temperature, respiration rate, $\mathrm{cu}-$ mulative BW change, cumulative BCS change, and DMI were analyzed by including a REPEATED model statement. The statistical model included treatment, time, and treatment by time. Cow within treatment was designated as a random effect. In addition, data from cumulative BW change, cumulative BCS change, and DMI were split into prepartum and postpartum periods (i.e., treatment and posttreatment) and analyzed separately. To avoid the effect of BW variation on DMI, BW values at $-21 \mathrm{~d}$ relative to expected calving and at calving were included in the SAS model as covariates to evaluate DMI values during prepartum and postpartum periods, respectively. Effects of the factors were declared significant at $P \leq 0.05$, unless otherwise noted, and trends were discussed at $P \leq 0.10$.

\section{RESULTS}

Average daily diurnal patterns of temperature, relative humidity, and THI as well as minimum, mean, and maximum THI are shown in Figures 1, 2, and 3. During the last $3 \mathrm{wk}$ of gestation, cows exposed to cooling had a lower rectal temperature $(P<0.001$; Table 2$)$ and a lower respiration rate $(P<0.001$; Table 2$)$ than those under heat stress.

No differences were observed in gestation period $(P$ $=0.29)$ and dry period lengths $(P=0.30)$ between HT and CL cows (Table 3). The subsequent number of inseminations per conception for CL and HT cows were 1.9 and 2.2 , respectively $(P=0.09$; Table 3$)$, but the number of days open did not differ $(P=0.22$; Table 3 ). Calf BW at birth was $2.7 \mathrm{~kg}$ less for calves born from HT cows than for calves born from CL cows $(P=$ 0.04; Table 3). Treatments had no effect on colostrum production $(P=0.44$; Table 3$)$. However, heat stress abatement during the last $3 \mathrm{wk}$ of gestation improved colostrum quality; colostrum density was greater in CL cows than in HT cows $(P=0.005$; Table 3$)$.

Cows under the CL treatment during the last 3 wk of gestation produced on average $4.1 \mathrm{~kg} / \mathrm{d}$ more milk than those under HT $(P=0.04$; Table 4$)$. Milk production adjusted for components (3.5\% FCM, 3.5\% fat- and protein-corrected milk, and ECM) across the postpartum period was greater for CL cows than for HT cows (Table 4; Figure 4). The CL cows had greater yields of protein $(P=0.002)$ and SNF $(P<0.001)$ than HT cows (Table 4$)$, whereas the numeric increase in milk fat yield did not reach significance $(P=0.13)$. However, no differences were found between treatments in the percentages of milk fat, protein, and SNF (all $P>0.10$; Table 4$)$ and both groups had similar SCS $(P=0.22$; Table 4). In addition, the CL cows had a greater feed 


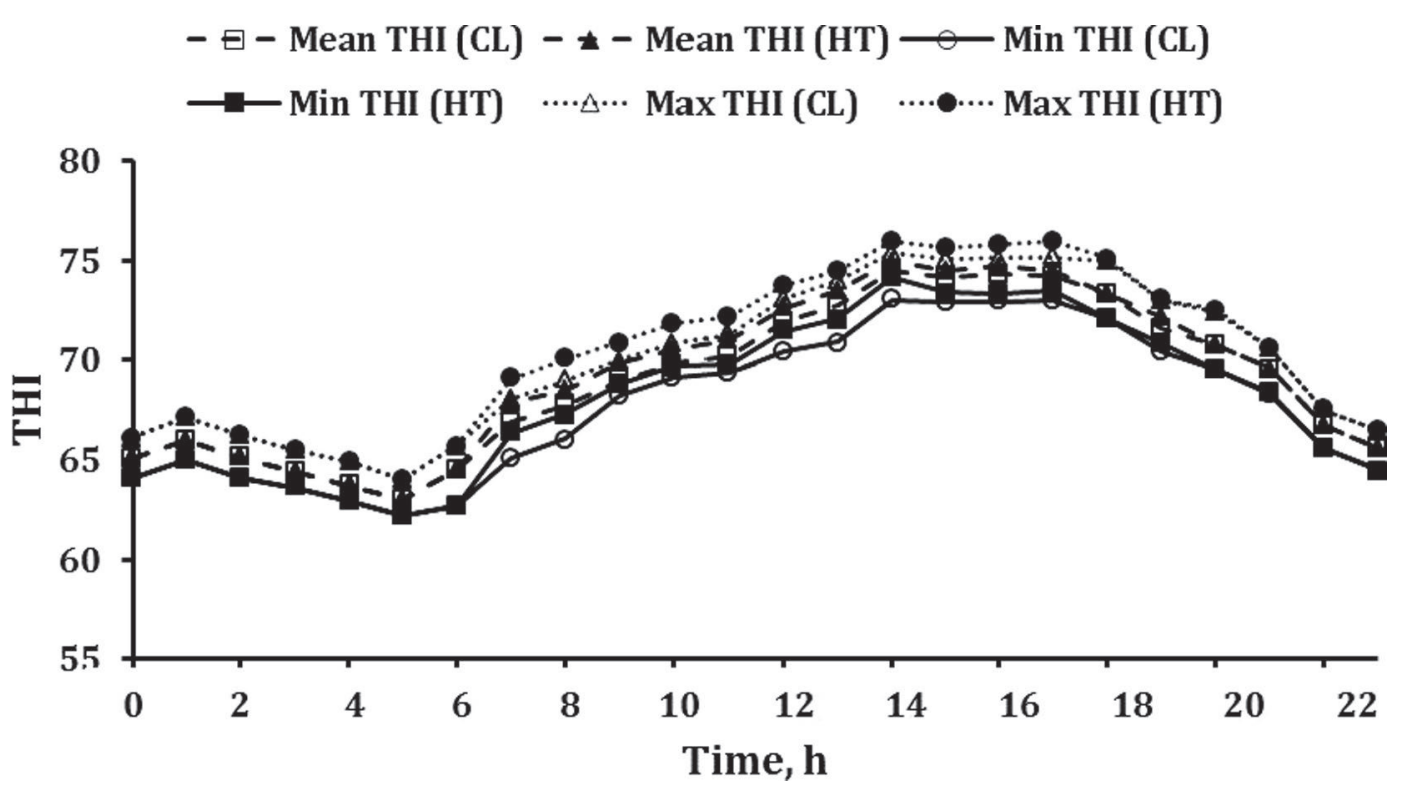

Figure 2. Average daily diurnal pattern of temperature-humidity index (THI) under cooling (CL) and heat stress (HT) conditions during the precalving period.

efficiency during the 180-d postpartum period than the HT cows $(P=0.04$; Table 4$)$.

Compared with cooling, heat stress during the last 3 wk of gestation decreased both actual DMI $(P=0.04)$ and DMI as a percentage of prepartum BW $(P=0.03$; Table 5); however, DMI did not differ between treatments postpartum (Table 5). In addition, the tendency $(P=0.07)$ for treatment by time interaction (Figure 5 ) indicated that CL cows tended to eat more than HT cows during the immediate postpartum period but the differences narrowed as lactation advanced. During the last 3 wk of gestation, HT cows tended to gain less BW than CL cows $(P=0.07$; Table 5$)$, but BW losses were not different after calving $(P=0.38$; Table 5$)$. Both groups had similar BCS changes during the last $3 \mathrm{wk}$ of gestation $(P=0.65$; Table 5$)$, but HT cows tended $(P=0.09)$ to have greater BCS change postpartum as compared with the CL group (Table 5).

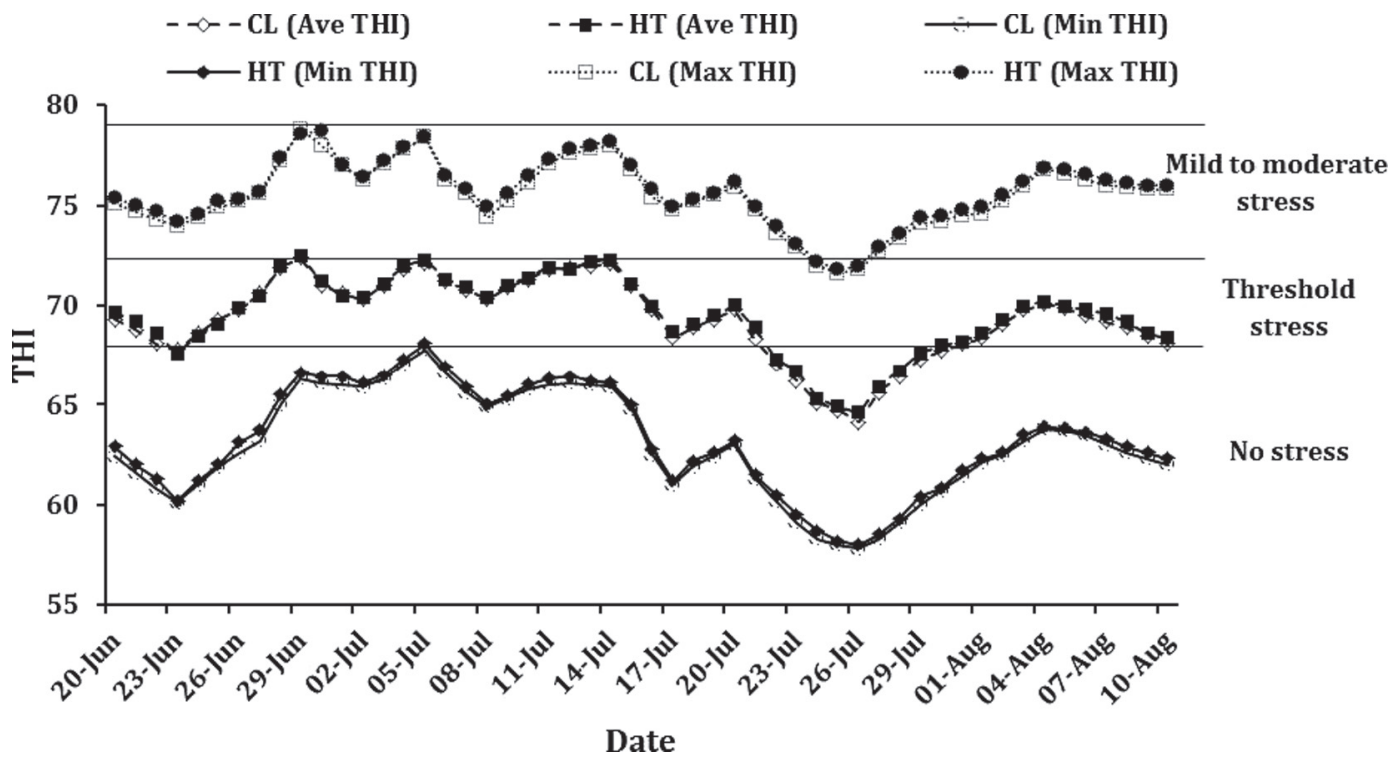

Figure 3. Temporal pattern of minimum (min), maximum (max), and average (ave) temperature-humidity index (THI) during the precalving period. Heat stress categories are those suggested by Zimbelman et al. (2009). 
Table 2. Rectal temperature and respiration rate of cows exposed to either heat stress (HT) or cooling (CL) during late gestation

\begin{tabular}{lllll}
\hline & \multicolumn{2}{c}{ Treatment } & & \\
\cline { 2 - 3 } Variable & $\mathrm{HT}$ & $\mathrm{CL}$ & SEM & $P$-value \\
\hline Rectal temperature, ${ }^{\circ} \mathrm{C}$ & 39.46 & 39.22 & 0.05 & $<0.001$ \\
Respiration rate, breaths $/ \mathrm{min}$ & 70.4 & 63.3 & 1.34 & $<0.001$ \\
\hline
\end{tabular}

Leucocyte abundance was not affected by cooling either at calving or at $45 \mathrm{~d}$ after calving $(P>0.10$; Table $6)$. Leucocyte class percentage was also not affected by treatments either at calving or at $45 \mathrm{~d}$ after calving $(P$ $>0.10$; Table 6 ).

Cooled cows tended $(P=0.06)$ to have greater chewing time $(58 \mathrm{~min} / \mathrm{d})$ as compared with HT cows, which was a reflection of longer ruminating time $(P=0.03)$ and a nonsignificant increase $(P=0.13)$ in eating time of cooled cows (Table 7 ). Both groups, however, spent the same time drinking $(P=0.45$; Table 7$)$. The number of meals $(P=0.23)$ and the number of ruminating bouts $(P=0.17)$ were not affected by treatments (Table 7$)$, but HT cows had shorter meal $(P=0.02)$ and rumination $(P=0.01)$ durations than their $\mathrm{CL}$ counterparts (Table 7). Standing time was shorter in CL cows than in HT cows $(P=0.007)$.

\section{DISCUSSION}

The THI was similar in both HT and CL treatment pens during the last $3 \mathrm{wk}$ of gestation, as designed. Cows may be cooled in either of 2 ways: direct cooling or cooling the ambient air. The cooling system used in the current experiment was designed for direct cooling of the animals rather than the ambient air. The observed THI value of greater than 68 in the barns where treatments were housed indicates that the cows were exposed to heat stress (Zimbelman et al., 2009). The decreased rectal temperature and respiration rate in the CL treatment indicate the effectiveness of the

Table 3. Reproduction variables, calf birth weight, and colostrum quality of cows exposed to either heat stress (HT) or cooling (CL) during late gestation

\begin{tabular}{|c|c|c|c|c|}
\hline \multirow[b]{2}{*}{ Variable } & \multicolumn{2}{|c|}{ Treatment } & \multirow[b]{2}{*}{ SEM } & \multirow[b]{2}{*}{$P$-value } \\
\hline & HT & CL & & \\
\hline Gestation period length, $\mathrm{d}$ & 277.0 & 278.3 & 1.19 & 0.29 \\
\hline Dry period length, d & 41.8 & 43.1 & 1.22 & 0.30 \\
\hline Services per conception & 2.2 & 1.9 & 0.16 & 0.09 \\
\hline Number of days open & 106.7 & 97.0 & 7.68 & 0.22 \\
\hline Calf birth weight, $\mathrm{kg}$ & 40.7 & 43.4 & 1.29 & 0.04 \\
\hline Colostrum production, $\mathrm{kg}$ & 8.5 & 9.2 & 0.80 & 0.44 \\
\hline Colostrum density, $\mathrm{g} / \mathrm{cm}^{3}$ & 1.056 & 1.065 & 0.003 & 0.005 \\
\hline
\end{tabular}

Table 4. Milk yield and milk composition and feed efficiency (180 d) of cows exposed to either heat stress (HT) or cooling (CL) during late gestation.

\begin{tabular}{|c|c|c|c|c|}
\hline \multirow[b]{2}{*}{ Variable } & \multicolumn{2}{|c|}{ Treatment } & \multirow[b]{2}{*}{ SEM } & \multirow[b]{2}{*}{$P$-value } \\
\hline & $\mathrm{HT}$ & CL & & \\
\hline \multicolumn{5}{|l|}{ Yield, $\mathrm{kg} / \mathrm{d}$} \\
\hline Actual milk & 40.5 & 44.6 & 2.01 & 0.04 \\
\hline $3.5 \% \mathrm{FCM}^{1}$ & 37.5 & 42.2 & 1.88 & 0.02 \\
\hline $3.5 \% \mathrm{FPCM}^{1}$ & 37.9 & 42.7 & 1.88 & 0.01 \\
\hline $\mathrm{ECM}^{1}$ & 38.3 & 43.2 & 1.88 & 0.01 \\
\hline Fat & 1.21 & 1.39 & 0.11 & 0.13 \\
\hline Protein & 1.27 & 1.43 & 0.04 & 0.002 \\
\hline SNF & 3.7 & 4.1 & 0.07 & $<0.001$ \\
\hline \multicolumn{5}{|l|}{ Composition, \% } \\
\hline Fat & 2.95 & 3.10 & 0.27 & 0.62 \\
\hline Protein & 3.09 & 3.17 & 0.10 & 0.45 \\
\hline SNF & 9.0 & 9.1 & 0.16 & 0.53 \\
\hline Fat:protein & 0.96 & 0.97 & 0.06 & 0.84 \\
\hline Milk SCS & 2.5 & 1.9 & 0.46 & 0.22 \\
\hline \multicolumn{5}{|l|}{ Feed efficiency } \\
\hline FCM/DMI & 2.06 & 2.22 & 0.10 & 0.04 \\
\hline
\end{tabular}

${ }^{1} 3.5 \% \mathrm{FCM}=(0.4324 \times$ milk yield $)+(16.216 \times$ milk fat yield $) ; 3.5 \%$ fat- and protein-corrected milk $=(12.82 \times \mathrm{kg}$ of fat $)+(7.13 \times \mathrm{kg}$ of protein $)+(0.323 \times \mathrm{kg}$ of milk $)$; and $\mathrm{ECM}=(0.327 \times \mathrm{kg}$ of milk $)+$ $(12.95 \times \mathrm{kg}$ of fat $)+(7.20 \times \mathrm{kg}$ of protein $)($ Tyrrell and Reid, 1965)

cooling system (fans and sprinklers) in reducing animal temperature. Moreover, the lower BW of the calves from the HT cows and the reduced BW of cows during the last $3 \mathrm{wk}$ of gestation are additional evidence indicating the presence of heat stress, which was partially alleviated in the CL treatment (Avendano-Reyes et al., 2006; do Amaral et al., 2011; Tao et al., 2012).

Similar to other late-gestation heat stress studies (Collier et al., 1982b; do Amaral et al., 2011; Tao et al., 2012), calves from the HT cows had lower birth weights $(2.8 \mathrm{~kg})$ than those from the CL cows. Several theories may explain the phenomenon. First, pregnancy length of cows under heat stress might be shorter. About $60 \%$ of fetal growth occurs during the last 2 mo of gestation (Bauman and Currie, 1980). If it is assumed that the expected ADG of the fetus in the uterus a Holstein dairy cow is $0.5 \mathrm{~kg}$ during the last week of gestation (Muller et al., 1975), the 1.3-d shorter pregnancy length in the HT cows compared with the CL cows in the current study should account for approximately $24 \%$ (0.65 $\mathrm{kg}$ ) of the reduced birth weight in the newborn HT calves. Second, undernourishment in late gestation may also reduce calf birth weight (Wu et al., 2006). In the current experiment, HT cows had an $11.4 \%$ reduction in DMI during the last 3 wk of gestation compared with CL cows. Whether the small decrease in DMI (10 to $15 \%$ ) in dry cows under heat stress could affect fetal growth is questionable; however, moderately decreased energy intake in late gestation does not affect calf birth weight in dairy or beef cattle (Janovick and Drackley, 


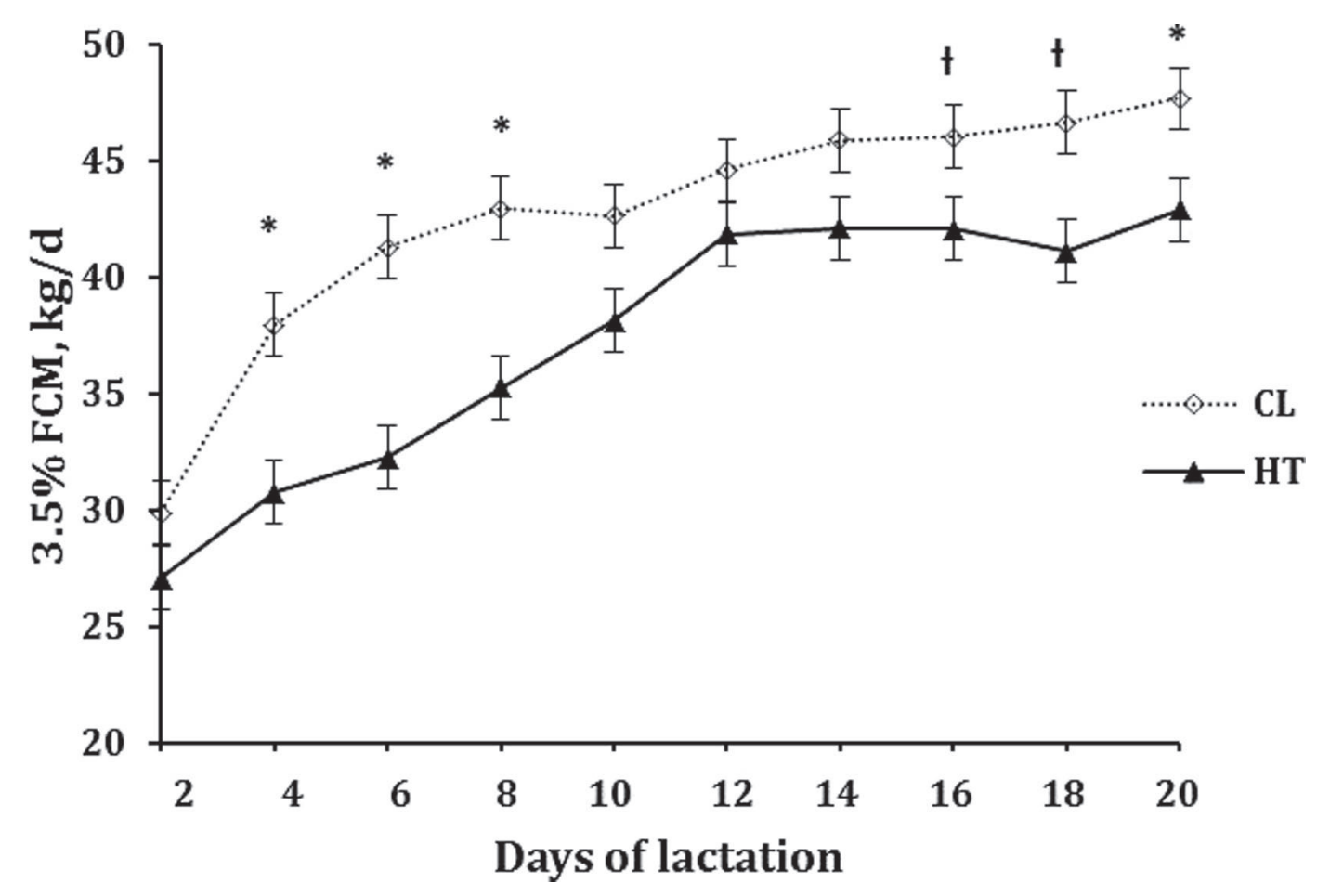

Figure 4. Effect of heat stress (HT, $\mathrm{n}=10 ; \mathbf{\square})$ and cooling $(\mathrm{CL}, \mathrm{n}=10 ; \diamond)$ during the last 3 wk of gestation on $3.5 \%$ FCM production in the subsequent lactation. Cows exposed to CL during the last 3 wk of gestation produced more milk than cows in HT up to $20 \mathrm{~d}$ in milk. $\left({ }^{*} P\right.$ $<0.05 ; \dagger P \leq 0.10)$. Error bars represent standard errors.

2010). Intrauterine growth retardation of heat-stressed ewes during late gestation has been found to be independent of malnutrition (Brown et al., 1977).

Finally, the effects of heat stress on pregnancy in ruminants are related not only to decreased blood flow to

Table 5. Dry matter intake during the first $3 \mathrm{wk}, \mathrm{BW}$, and BCS changes of cows exposed to either heat stress (HT) or cooling (CL) during late gestation

\begin{tabular}{lccrc}
\hline & \multicolumn{2}{c}{ Treatment } & & \\
\cline { 2 - 3 } Variable & HT & CL & SEM & $P$-value \\
\hline Prepartum & & & & \\
DMI, kg/d & 13.7 & 15.5 & 0.82 & 0.04 \\
DMI, \% BW & 1.90 & 2.16 & 0.11 & 0.03 \\
BW change & -40.7 & -31.7 & 4.78 & 0.07 \\
BCS change & -0.18 & -0.13 & 0.11 & 0.65 \\
Postpartum & & & & \\
DMI, kg/d & 18.2 & 19.0 & 0.75 & 0.30 \\
DMI, \% BW & 2.73 & 2.85 & 0.09 & 0.32 \\
BW change $^{2}$ & -127.8 & -114.4 & 15.03 & 0.38 \\
BCS change $^{2}$ & -1.23 & -0.78 & 0.25 & 0.09 \\
\hline
\end{tabular}

${ }^{1}$ Prepartum accumulative BW and BCS changes were calculated by subtracting data at -14 and $-7 \mathrm{~d}$ relative to calving and calving by data at $-21 \mathrm{~d}$.

${ }^{2}$ Postpartum accumulative BW and BCS changes were calculated by subtracting data at 7,14 , and $21 \mathrm{~d}$ relative to calving by data at calving. the uterus (Reynolds et al., 1985), but also to decreased placental size (Collier et al., 1982a) and function (Collier et al., 1982b; Bell et al., 1989). In turn, these factors limit oxygen diffusion into the fetal circulation (Dreiling et al., 1991) and impair maternal to fetal exchange of nutrients including glucose and AA (Reynolds et al., 1985). To deal with this phenomenon, the ruminant fetus uses a series of endocrine and metabolic adaptations to prevail over heat stress-associated hypoxemia and underfeeding (Yates et al., 2011). Furthermore, environmental-induced hyperthermia may have a direct negative effect on fetal growth as well as the maternal and placental effects. In pregnant ewes and goats under heat stress, fetal body temperature has been found to rise in parallel with maternal temperature (Faurie et al., 2001). Fetal hyperthermia has a more direct bearing on fetal development than placental insufficiency (Bell et al., 1989). Thus, the remaining $76 \%$ (2.05 kg) of the decreased fetal growth in HT calves compared with CL cows must be related to intrauterine growth retardation and fetal hyperthermia.

In agreement with other studies (do Amaral et al., 2009; Tao et al., 2011, 2012), HT cows in our study were observed to consume less DM than CL cows during the last 3 wk of gestation. Even though no treatment effect was observed on DMI during the postpartum 


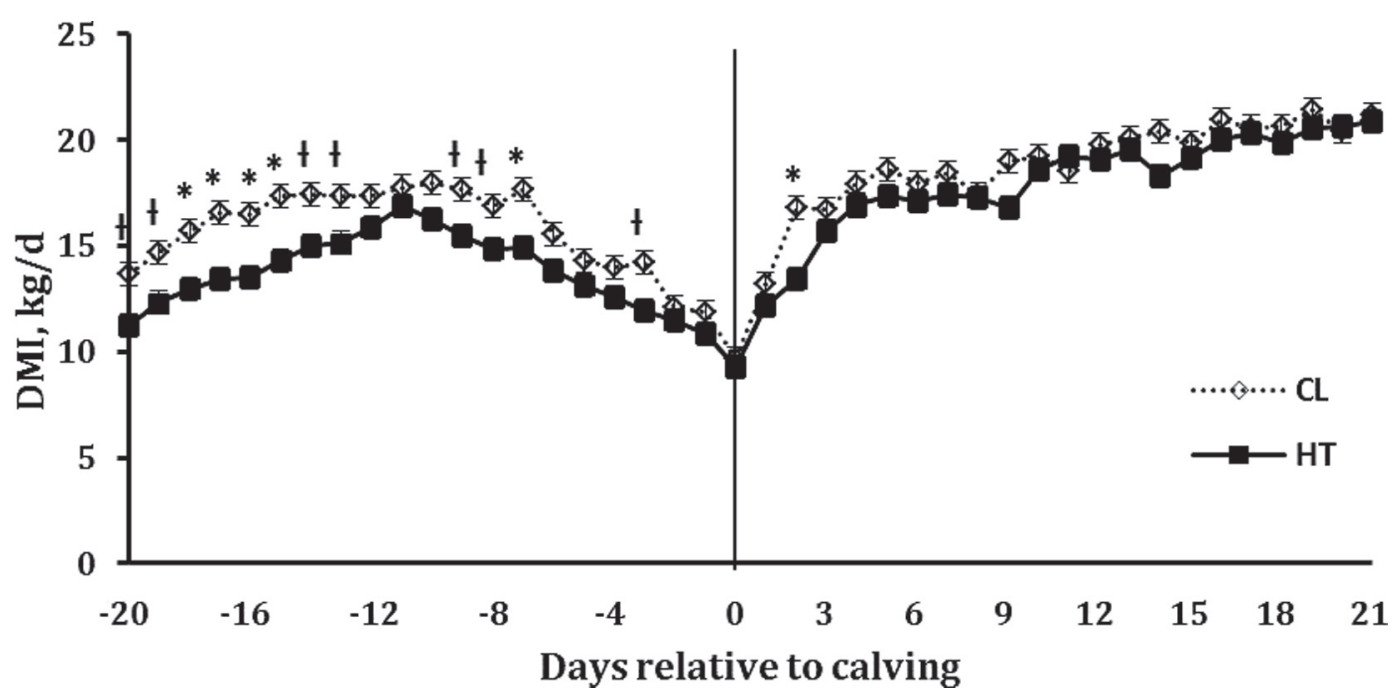

Figure 5. Effect of heat stress $(\mathrm{HT}, \mathrm{n}=10 ; \boldsymbol{\square})$ and cooling $(\mathrm{CL}, \mathrm{n}=10 ; \diamond)$ during the last 3 wk of gestation on DMI from -20 to $+21 \mathrm{~d}$ relative to calving. Data for prepartum and postpartum periods were analyzed separately. Body weights at $-21 \mathrm{~d}$ relative to expected calving and at calving were included as covariates during the prepartum and postpartum periods, respectively. The CL cows had greater DMI during the prepartum period compared with $\mathrm{HT}$ cows $\left({ }^{*} P<0.05 ; \dagger P \leq 0.10\right)$. Postpartum, an interaction of treatment and time tended to occur for DMI $(P=0.07)$; CL cows at +2 d relative to calving had greater DMI than for HT cows $(* P<0.05)$. Error bars represent standard errors.

period, a tendency of treatment by time interaction was observed (Figure 5), which may reflect the higher nutrient demand of CL cows compared with HT cows due to their greater milk yield. It may be suggested that the reduced DMI in HT cows was the result of statistically significant differences in rectal temperature between the 2 groups because the effect of heat stress is probably mediated through the effect of increasing body temperature on cow performance (West, 2003). Given the increased DMI in CL cows and the insignificant differences in BCS changes during the last 3 wk of gestation in both groups, the increasing DMI (\% BW) observed in CL cows is not unexpected. During the last 3 wk of gestation, CL cows gained more BW than HT cows, which is probably the result of the higher DMI and, perhaps, lower maintenance requirements in CL cows. The increased BW of CL cows during the last 3 wk of gestation may be the result of greater fetal growth, as no significant BCS changes were observed during the last 3 wk of gestation. In the current study no significant differences were observed in BW or BCS changes between the 2 treatments during the postpartum period, which suggests that both groups had similar adipose tissue mobilization in early lactation so that significant differences would not be expected in NEFA concentrations in plasma. This expectation has been confirmed by Tao et al. (2011), who reported that cows exposed to cooling during the dry period had similar NEFA concentrations in early lactation as compared with cows exposed to heat stress.

Table 6. Blood leukocyte profiles of cows exposed to either heat stress (HT) or cooling (CL) during late gestation

\begin{tabular}{lcccc}
\hline & \multicolumn{2}{c}{ Treatment } & & \\
\cline { 2 - 3 } Variable & HT & CL & SEM & P-value \\
\hline At calving & & & & \\
$\quad$ Leucocyte abundance, $\times 10^{3} / \mu \mathrm{L}$ & 7.8 & 8.4 & 1.67 & 0.72 \\
Neutrophil, \% & 34.7 & 33.2 & 5.52 & 0.79 \\
Lymphocyte, $\%$ & 61.7 & 62.0 & 6.30 & 0.95 \\
Residual, \% & 3.7 & 4.8 & 2.72 & 0.69 \\
Neutrophil:lymphocyte & 0.63 & 0.60 & 0.16 & 0.85 \\
At 45 DIM & & & & \\
Leucocyte abundance, $\times 10^{3} / \mu \mathrm{L}$ & 7.6 & 8.3 & 1.43 & 0.57 \\
Neutrophil, \% & 31.6 & 30.9 & 3.97 & 0.87 \\
Lymphocyte, \% & 60.6 & 61.9 & 4.68 & 0.78 \\
Residual, \% & 7.9 & 7.6 & 2.56 & 0.90 \\
Neutrophil:lymphocyte & 0.55 & 0.53 & 0.10 & 0.82 \\
\hline
\end{tabular}


Table 7. Chewing activities, meal and rumination patterns, drinking time, and standing time at $10 \mathrm{~d}$ before expected calving of cows exposed to either heat stress (HT) or cooling (CL)

\begin{tabular}{|c|c|c|c|c|}
\hline \multirow[b]{2}{*}{ Variable } & \multicolumn{2}{|c|}{ Treatment } & \multirow[b]{2}{*}{ SEM } & \multirow[b]{2}{*}{$P$-value } \\
\hline & HT & CL & & \\
\hline \multicolumn{5}{|l|}{ Eating time } \\
\hline $\min / \mathrm{d}$ & 147.4 & 166.2 & 12.13 & 0.13 \\
\hline $\min / \mathrm{kg}$ of $\mathrm{DM}$ & 10.8 & 10.8 & 0.83 & 0.99 \\
\hline \multicolumn{5}{|l|}{ Meals } \\
\hline Bouts/d & 11.4 & 10.2 & 0.97 & 0.23 \\
\hline Length, $\min /$ meal & 14.2 & 16.8 & 1.06 & 0.02 \\
\hline \multicolumn{5}{|l|}{ Ruminating time } \\
\hline $\min / \mathrm{d}$ & 243.2 & 282.5 & 17.22 & 0.03 \\
\hline $\min / \mathrm{kg}$ of $\mathrm{DM}$ & 17.8 & 18.3 & 1.18 & 0.66 \\
\hline \multicolumn{5}{|l|}{ Rumination } \\
\hline Bouts/d & 13.1 & 11.3 & 1.2 & 0.17 \\
\hline Bout length, $\mathrm{min} / \mathrm{meal}$ & 19.4 & 25.5 & 2.2 & 0.01 \\
\hline \multicolumn{5}{|l|}{ Total chewing time } \\
\hline $\min / \mathrm{d}$ & 390.6 & 448.7 & 28.8 & 0.06 \\
\hline $\min / \mathrm{kg}$ of $\mathrm{DM}$ & 28.5 & 29.0 & 1.90 & 0.79 \\
\hline \multicolumn{5}{|l|}{ Drinking time } \\
\hline $\min / \mathrm{d}$ & 8.1 & 7.6 & 0.66 & 0.45 \\
\hline \multicolumn{5}{|l|}{ Standing time } \\
\hline $\mathrm{min} / \mathrm{d}$ & 474.0 & 390.4 & $28.8 r$ & 0.007 \\
\hline
\end{tabular}

Experimental treatments were found to have no effects on colostrum yield. This result is in agreement with the findings of Nardone et al. (1997), who reported no differences in colostrum yields of between groups of heifers subjected to HT and CL conditions during the final $2 \mathrm{wk}$ of pregnancy. It might be that stressors and physiological changes at calving hindered colostrum release in their animals. In our study, colostrum density was used as an index for describing colostrum quality and CL cows exhibited a higher colostrum density than the HT group. Colostrum density is an approximate index of total colostrum protein per unit volume; but colostrum quality is measured in terms of its immunoglobulin, especially IgG, concentration. In contrast to the present experiment, other researchers used IgG concentration as an index to assess colostrum quality. They found no differences in colostrum IgG concentration between cows under HT and CL treatments during late gestation period (Tao et al., 2012). Others (Nardone et al., 1997; Adin et al., 2009), however, reported reduced colostrum IgG concentration due to late gestation heat stress.

The results of the current study confirm the findings of previous studies that CL treatment during the last 3 wk of gestation increases milk production compared with HT (do Amaral et al., 2009; Tao et al., 2011, 2012). It has been reported that late gestation cooling methods and duration affect milk yield responses in subsequent lactations. For instance, the use of shade (Collier et al., 1982b) or short interval soaking in the middle of the day (Avendano-Reyes et al., 2006) have been found to lead to a modest increase in subsequent milk production, but the effect was not statistically significant. However, when more extensive cooling (shade, fans, and sprinklers) was provided to dry cows (as in the current experiment), milk production significantly improved in subsequent lactations (Tao et al., 2011). Prepartum cooling duration under ambient heat stress may also affect future lactation performance. In a controlled study, cows actively cooled in the last $28 \mathrm{~d}$ of their gestation period exhibited improved milk yield in the first $60 \mathrm{~d}$ of lactation compared with noncooled cows (Urdaz et al., 2006). Interestingly, milk yield by the cows in the current study improved until 180 DIM when actively cooled during the last $21 \mathrm{~d}$ of gestation.

Some researchers (do Amaral et al., 2011; Tao et al., 2011) have observed increased milk protein yields in CL cows, whereas do Amaral et al. (2009) did not. Similar to other reports (do Amaral et al., 2009, 2011; Tao et al., 2011), milk fat yield in our study was found to be numerically greater in CL cows than in HT cows. No definite results have been reported on the effect of heat stress during the precalving period on milk fat concentration. do Amaral et al. $(2009,2011)$ reported decreased milk fat concentration due to heat stress during the precalving period, whereas Adin et al. (2009) and Tao et al. (2011) did not observe any such effect or any difference between their treatments. In the current study, heat stress during the last 3 wk of gestation did not affect milk fat concentration in subsequent lactation.

Inconsistent reproductive responses after late gestation cooling have been observed. For example, Avendano-Reyes et al. (2006) reported that cows under heat stress during the dry period, compared with their cooled counterparts, had more days open and increased services per conception in subsequent lactation. In contrast, Adin et al. (2009) reported no differences with regard to reproductive traits between cows subjected to prepartum heat stress or cooling. In the present study, open days were not affected by treatment, but HT cows had more services per conception in their subsequent lactation.

To the best of our knowledge, the present experiment is the first of its kind evaluating the effects of heat stress during the last 3 wk of gestation on prepartum behavioral changes in cows. Not unexpectedly, ruminating and chewing times and (numerically) eating time were found to be shorter in HT cows $10 \mathrm{~d}$ before their expected calving date, but eating time per DMI, ruminating time per DMI, and chewing time per kilogram of DMI were not affected by experimental treatments. Based on our study, it may be concluded that prepartum dairy cows adapt to heat stress through increasing meals and reducing meal durations. 


\section{CONCLUSIONS}

Heat stress during the last 3 wk of gestation disturbed cow welfare and decreased DMI, BW gains of cows, calf birth weight, and colostrum density. Moreover, heat stress led to decreased milk production and reproductive performance in subsequent lactation. Therefore, using a cooling system seems to be essential for heat stress abatement, which will, in turn, increase productivity of Holstein dairy cows and decrease economic losses.

\section{ACKNOWLEDGMENTS}

The authors thank Isfahan University of Technology (IUT, Isfahan, Iran) for funding this research and especially for providing suitable experimental conditions. The authors express their kind appreciation to the farm staff at Lavark, the farm animal research and teaching unit (IUT, Isfahan, Iran), for diligent animal care and technical assistance.

\section{REFERENCES}

Adin, G., A. Gelman, R. Solomon, I. Flamenbaum, M. Nikbachat, E. Yosef, A. Zenou, A. Shamay, Y. Feuermann, S. J. Mabjeesh, and J. Miron. 2009. Effects of cooling dry cows under heat load conditions on mammary gland enzymatic activity, intake of food water, and performance during the dry period and after parturition. Livest. Sci. 124:189-195.

AOAC International. 2002. Official Methods of Analysis. Vol. 1. 17th ed. AOAC International, Arlington, VA.

Avendano-Reyes, L., F. D. Alvarez-Valenzuela, A. Correa-Calderon, J. S. Saucedo-Quintero, P. H. Robinson, and J. G. Fadel. 2006. Effect of cooling Holstein cows during the dry period on postpartum performance under heat stress conditions. Livest. Sci. 281:2535-2547.

Bauman, D. E., and W. B. Currie. 1980. Partitioning of nutrients during pregnancy and lactation: A review of mechanisms involving homeostasis and homeorhesis. J. Dairy Sci. 63:1514-1529.

Bell, A. W., B. W. McBride, R. Slepetis, R. J. Early, and W. B. Currie. 1989. Chronic heat stress and prenatal development in sheep: I. Conceptus growth and maternal plasma hormones and metabolites. J. Anim. Sci. 67:3289-3299.

Brown, D. E., P. C. Harrison, F. C. Hinds, J. A. Lewis, and M. H Wallace. 1977. Heat stress effects on fetal development during late gestation in the ewe. J. Anim. Sci. 44:442-446.

Collier, R. J., D. K. Beede, W. W. Thatcher, L. A. Israel, and C. J. Wilcox. 1982a. Influences of environment and its modification on dairy animal health and production. J. Dairy Sci. 65:2213-2227.

Collier, R. J., G. E. Dahl, and M. J. VanBaale. 2006. Major advances associated with environmental effects on dairy cattle. J. Dairy Sci. 89:1244-1253.

Collier, R. J., S. G. Doelger, H. H. Head, W. W. Thatcher, and C. J. Wilcox. 1982b. Effects of heat stress during pregnancy on maternal hormone concentrations, calf birth weight and postpartum milk yield of Holstein cows. J. Anim. Sci. 54:309-319.

Dikmen, S., and P. J. Hansen. 2009. Is the temperature-humidity index the best indicator of heat stress in lactating dairy cows in a subtropical environment? J. Dairy Sci. 92:109-116.

do Amaral, B. C., E. E. Connor, S. Tao, J. Hayen, J. Bubolz, and G. E. Dahl. 2009. Heat stress abatement during the dry period: Does cooling improve transition into lactation? J. Dairy Sci. 92:59885999. do Amaral, B. C., E. E. Connor, S. Tao, M. J. Hayen, J. W. Bubolz, and G. E. Dahl. 2010. Heat stress abatement during the dry period influences prolactin signaling in lymphocytes. Domest. Anim. Endocrinol. 38:38-45.

do Amaral, B. C., E. E. Connor, S. Tao, M. J. Hayen, J. W. Bubolz, and G. E. Dahl. 2011. Heat stress abatement during the dry period influences metabolic gene expression and improves immune status in the transition period of dairy cows. J. Dairy Sci. 94:86-96.

Drackley, J. K. 1999. Biology of dairy cows during the transition period: The final frontier? J. Dairy Sci. 82:2259-2273.

Dreiling, C. E., F. S. Carman III, and D. E. Brown. 1991. Maternal endocrine and fetal metabolic responses to heat stress. J. Dairy Sci. 74:312-327.

Faurie, A. S., D. Mitchell, and H. P. Laburn. 2001. Feto-maternal relationships in goats during heat and cold exposure. Exp. Physiol. 86:199-204.

Fox, D. G., T. P. Tylutki, K. J. Czymmek, C. N. Rasmussen, and V. M. Durbal. 2000. Development and application of the Cornell University nutrient management planning system. Pages 167-179 in Proc. Cornell Nutr. Conf. Feed Manuf., Rochester, NY. Cornell Univ., Ithaca, NY.

Grummer, R. R., and R. R. Rastani. 2004. Why reevaluate dry period length? J. Dairy Sci. 87(E. Suppl.):E77-E85.

Huzzey, J. M., M. A. G. von Keyserlingk, and D. M. Weary. 2005. Changes in feeding, drinking and standing behavior of dairy cows during the transition period. J. Dairy Sci. 88:2454-2461.

Janovick, N. A., and J. K. Drackley. 2010. Prepartum dietary management of energy intake affects postpartum intake and lactation performance by primiparous and multiparous Holstein cows. J. Dairy Sci. 93:3086-3102.

Kargar, S., G. R. Ghorbani, V. Fievez, and D. J. Schingoethe. 2015 Performance, bioenergetic status, and indicators of oxidative stress of environmentally heat-loaded Holstein cows in response to diets inducing milk fat depression. J. Dairy Sci. 98:4772-4784. http:// dx.doi.org/10.3168/jds.2014-9100.

Kargar, S., G. R. Ghorbani, M. Khorvash, E. Kamalian, and D. J. Schingoethe. 2013. Dietary grain source and oil supplement: Feeding behavior and lactational performance of Holstein cows. Livest. Sci. 157:162-172.

Kargar, S., G. R. Ghorbani, M. Khorvash, A. Sadeghi-Sefidmazgi, and D. J. Schingoethe. 2014. Reciprocal combinations of barley and corn grains in oil-supplemented diets: Feeding behavior and milk yield of lactating cows. J. Dairy Sci. 97:7001-7011.

Kargar, S., M. Khorvash, G. R. Ghorbani, M. Alikhani, and W. Z. Yang. 2010. Short communication: Effects of dietary fat supplements and forage:concentrate ratio on feed intake, feeding, and chewing behavior of Holstein dairy cows. J. Dairy Sci. 93:42974301

Mallard, B. A., J. C. Dekkers, M. J. Ireland, K. E. Leslie, S. Sharif, C. L. Vankampen, L. Wagter, and B. N. Wilkie. 1998. Alteration in immune responsiveness during the prepartum period and its ramification on dairy cow and calf health. J. Dairy Sci. 81:585-595.

Muller, L. D., G. L. Beardsley, R. P. Ellis, D. E. Reed, and M. J. Owens. 1975. Calf response to the initiation of parturition in dairy cows with dexamethasone or dexamethasone with estradiol benzoate. J. Anim. Sci. 41:1711-1716.

Nardone, A., N. Lacetera, U. Bernabucci, and B. Ronchi. 1997. Composition of colostrum from dairy heifers exposed to high air temperatures during late pregnancy and the early postpartum period. J. Dairy Sci. 80:838-844.

Reynolds, L. P., C. L. Pealal, and J. A. Nienaber. 1985. Effects of chronic environmental heat stress on blood flow and nutrient uptake of the gravid bovine uterus and fetus. J. Agric. Sci. 104:289297.

SAS Institute. 2002. SAS User's Guide: Statistics. Version 9.1. SAS Institute Inc., Cary, NC.

Tao, S., J. W. Bubolz, B. C. do Amaral, I. M. Thompson, M. J. Hayen, S. E. Johnson, and G. E. Dahl. 2011. Effect of heat stress during the dry period on mammary gland development. J. Dairy Sci. 94:5976-5986. 
Tao, S., A. P. Monteiro, I. M. Thompson, M. J. Hayen, and G. E. Dahl. 2012. Effect of late-gestation maternal heat stress on growth and immune function of dairy calves. J. Dairy Sci. 95:7128-7136.

Tyrrell, H. F., and J. T. Reid. 1965. Prediction of the energy value of cow's milk. J. Dairy Sci. 48:1215-1223.

Urdaz, J. H., M. W. Overton, D. A. Moore, and J. E. P. Santos. 2006. Technical note: Effects of adding shade and fans to a feed bunk sprinkler system for periparturient cows on health and performance. J. Dairy Sci. 89:2000-2006.

Van Soest, P. J., J. B. Robertson, and B. A. Lewis. 1991. Methods for dietary fiber, neutral detergent fiber, and non-starch polysaccharide in relation to animal nutrition. J. Dairy Sci. 74:3583-3597.

West, J. W. 2003. Effects of heat-stress on production in dairy cattle. J. Dairy Sci. 86:2131-2144.
Wu, G., F. W. Bazer, J. M. Wallace, and T. E. Spencer. 2006. Boardinvited review: Intrauterine growth retardation: Implications for the animal sciences. J. Anim. Sci. 84:2316-2337.

Yates, D. T., A. S. Green, and S. W. Limesand. 2011. Catecholamines mediate multiple fetal adaptations during placental insufficiency that contribute to intrauterine growth restriction: Lessons from hyperthermic sheep. J. Pregnancy 2011:740408.

Zimbelman, R. B., R. P. Rhoads, M. L. Rhoads, G. C. Duff, L. H. Baumguard, and R. J. Collier. 2009. A re-evaluation of the impact of temperature humidity index (THI) and black globe temperature humidity index (BGHI) on milk production in high producing dairy cows. Pages 158-168 in Proc. 24th Southwest Nutr. Mgmt. Conf, Tempe, AZ. University of Arizona, Tucson. 